\title{
Sustainable Bio-Conversion of Rice Straw Waste into High Quality Organic Fertilizer
}

\author{
Hala M. Omar'1, Yahia I. Mahmoud², Salah M. El-Haggar' \\ ${ }^{1}$ Department of Mechanical Engineering, The American University in Cairo, Cairo, Egypt \\ ${ }^{2}$ Soil Microbiology Department, Soil, Water and Environment Research Institute, Agriculture Research Center, Ministry of \\ Agriculture, Giza, Egypt \\ Email: halaomar@aucegypt.edu
}

How to cite this paper: Omar, H.M., Mahmoud, Y.I. and El-Haggar, S.M. (2020) Sustainable Bio-Conversion of Rice Straw Waste into High Quality Organic Fertilizer. Journal of Environmental Protection, 11, 315-331.

https://doi.org/10.4236/jep.2020.114018

Received: March 2, 2020

Accepted: April 6, 2020

Published: April 9, 2020

Copyright (c) 2020 by author(s) and Scientific Research Publishing Inc. This work is licensed under the Creative Commons Attribution International License (CC BY 4.0).

http://creativecommons.org/licenses/by/4.0/

Open Access

\begin{abstract}
The aim of this study is to investigate the effect of different additives including biochar, effective micro-organisms (EM), animal manure and commercial microbial inoculants on the bioconversion of rice straw. Different compost piles were constructed, and each contained $50 \mathrm{~kg}$ of rice straw and mixture of natural rocks to enrich the compost nutritional value. The physical, chemical and biological parameters indicating the decomposition of organic material, maturation and quality of the organic fertilizer product were investigated during the composting process. A rapid increase in compost temperature was obtained in inoculated piles. All piles reached maturation after around 42 days. All analysis of the properties of the final compost products indicated that it was in the range of the matured level and can be used as organic fertilizer without limitation. The highest decomposition rate and highest organic fertilizer quality were obtained in the pile inoculated with EM and 10\% biochar compared to other treatments.
\end{abstract}

\section{Keywords}

Biochar, Effective Micro-Organisms, Organic Fertilizer, Rice Straw

\section{Introduction}

Egypt generates up to 30 million ton/year of agricultural waste [1]. Almost half of it is directly burnt in the field [2]. Rice straw is one of the main types of agricultural waste generated in Egypt. In fact, it was estimated that around 5.9 million ton of rice straw used to be generated in 2013 [3]. Part of this rice straw is used at an individual level as a source of fuel for household cooking and heating, animal feed, fiber for pulping and plowing into farmland. Yet, the rest is 
dumped and burned in open fields causing serious environmental problems, including air pollution and soil degradation [3] [4]. Therefore, it became imperative to find efficient and cost-effective methods to reduce environmental pollution and recycle agricultural resources.

Rice straw contains cellulose, hemicellulose and lining, which makes it hard to decompose. However, several studies showed that rice straw could be used to produce high value-added products via composting process [5] [6].

Composting is an aerobic fermentation process that converts large amounts of agricultural waste into high quality soil amendment and/or organic fertilizer [3] [7] [8] [9], which can be used instead of the expensive and imported chemical fertilizers. The compost pile goes through four phases: 1) mesophilic phase is a preparatory stage, which initiates organic matter decomposition; 2) thermophilic phase in which microorganisms decompose organic matter at high temperatures ranging from $40^{\circ} \mathrm{C}-70^{\circ} \mathrm{C} ; 3$ ) second mesophilic phase allowing re-establishment of the heat resistant microbes; and 4) maturity phase of constant nutrient contents [10] [11] [12] [13]. Although composting has been widely practiced, the process is still not fully understood due to high variety and heterogeneity of feedstocks [9]. The objective of composting is to accelerate and create optimum conditions for the naturally occurring decomposition process to take place.

Some studies showed that inoculating compost piles with different additives, including biochar, effective micro-organisms (EM), cellulose decomposing bacteria, starters containing bacillus, fungi, yeast, lactic acid bacteria, and animal manure, can improve the nutritional value of compost and/or organic fertilizer and accelerate the degradation process [14] [15]. Several producers of these additives claim that they can generate higher quality organic fertilizer during short period of time. Yet, the effect of these additives on the composting process is not fully studied and understood. The aim of this paper is to evaluate and compare the effect of inoculating different types of additives on composting of rice straw.

\section{Materials and Methods}

\subsection{Raw Material}

Rice straw is the main raw material used for composting in this experiment. Rice straw was sun dried and chopped. The properties of rice straw used are analysed for nutrients, heavy metals, physicochemical and are presented in Table 1.

\subsection{Additives}

Animal manure, commercial microbial inoculants imported from China, effective micro-organisms (EM), and biochar were inoculated to rice straw and the quality of the final compost was evaluated. Based on the literature, different inoculation rates were determined.

Regarding the animal manure many studies showed that co-composting with animal manure provide high nutrient content of the compost. Studied reported the addition of animal manure at rates varying from $30 \%$ [16] [17] to $60 \%$ [9]. 
Table 1. Properties of rice straw.

\begin{tabular}{ccc}
\hline Parameters & Units & Value \\
\hline Density & $\mathrm{Kg} / \mathrm{m}^{3}$ & 72 \\
Moisture Content & $\%$ & 8.35 \\
$\mathrm{pH}$ & & 6.37 \\
Electrical conductivity (Ec) & $\mathrm{dS} / \mathrm{m}$ & 2.64 \\
Total Nitrogen & $\%$ & 0.612 \\
Organic matter & $\%$ & 82.19 \\
Organic carbon & $\%$ & 47.67 \\
Ash & $\%$ & 17.81 \\
C/N ratio & & $77.89: 1$ \\
Total phosphorus $\left(\mathrm{P}_{2} \mathrm{O}_{5}\right)$ & $\%$ & 0.34 \\
Total Potassium $\left(\mathrm{K}_{2} \mathrm{O}\right)$ & $\%$ & 0.517 \\
Dry matter & $\%$ & 91.65 \\
Crude protein & $\%$ & 3.76 \\
Humicellulose & $\mathrm{mg} / \mathrm{kg}$ & 24.88 \\
Cellulose & $\%$ & 40.26 \\
Lignin & $\%$ & 14.2 \\
Mn & $\% \mathrm{~kg}$ & 67 \\
Zn & $\%$ & 41 \\
\hline
\end{tabular}

Based on that, $40 \%$ of animal manure was added to rice straw in all treatments in this experiment.

In this study, a commercial microbial inoculants imported from China is used. It mainly contains lactic acid bacteria, yeasts, photosynthetic bacterial, etc. Their exact composition is not revealed and is seen as trade secret. No published studies have reported their exact composition nor their effect on composting process.

Another inoculant used in this experiment is EM, which consists of various strains of naturally occurring anaerobic nontoxic and non-pathogenic microorganisms in a carbohydrate-rich liquid carrier substrate (molasses nutrient solution). One part of commercial EM (EM-1) solution, produced by Egyptian Ministry of Agriculture, was added to one part of molasses and mixed with 20 parts of water to active EM solution and $100 \mathrm{~mL}$ of active solution was added to $50 \mathrm{~kg}$ of rice straw as recommended [17].

Recent studies have reported that biochar can be beneficial to the composting process. These studies reported application rates varying from $3 \%$ to $50 \%$. According to Sanchez Monedero et al., the recommended application dose of biochar to compost is around 10\% [18]. Some studies have also reported use of higher doses up to $50 \%$; however, some authors have reported that doses higher 
than $20 \%$ can slow down the composting process [19]. Therefore, doses of $10 \%$ and $20 \%$ are used in this study.

\subsection{Composting Procedure}

The composting process took place at the American University in Cairo during the months of May, June and July. Rice straw is added to nine large fabric bags; each pile is mixed with natural rocks and inoculated with different additives as summarized in Table 2 and Table 3. Each pile is manually turned and water is added every week. The chemical, physical and biological parameters of all samples have been analyzed as per standards and specifications [20]-[25].

\subsection{Statistical Analysis}

All results are presented as the average of three replicates, and the means among different treatments are compared using one-way ANOVA using SPPS version 23. The null hypothesis states that the population means are all equal. A significance level $\alpha=0.05$ is used. The ANOVA analysis is performed on the data

Table 2. Piles content used for composting process.

\begin{tabular}{|c|c|}
\hline $\begin{array}{l}\text { Treatment } \\
\text { No. }\end{array}$ & Pile Content \\
\hline $\mathrm{T} 1$ & $50 \mathrm{~kg}$ of rice straw $+20 \mathrm{~kg}$ of animal manure + Mixture of Rocks \\
\hline $\mathrm{T} 2$ & $\begin{array}{l}50 \mathrm{~kg} \text { of rice straw }+20 \mathrm{~kg} \text { of animal manure }+50 \mathrm{~g} \text { of Chinese starter }+ \text { Mixture of } \\
\text { Rocks }\end{array}$ \\
\hline T3 & $50 \mathrm{~kg}$ of rice straw $+20 \mathrm{~kg}$ of animal manure $+1 \mathrm{~L}$ of activated $\mathrm{EM}+$ Mixture of Rocks \\
\hline $\mathrm{T} 4$ & $50 \mathrm{~kg}$ of rice straw $+20 \mathrm{~kg}$ of animal manure $+5 \mathrm{~kg}$ biochar $(10 \%)+$ Mixture of Rocks \\
\hline $\mathrm{T} 5$ & $\begin{array}{l}50 \mathrm{~kg} \text { of rice straw }+20 \mathrm{~kg} \text { of animal manure }+50 \mathrm{~g} \text { of Chinese starter }+5 \mathrm{~kg} \text { of biochar } \\
(10 \%)+\text { Mixture of Rocks }\end{array}$ \\
\hline T6 & $\begin{array}{l}50 \mathrm{~kg} \text { of rice straw }+20 \mathrm{~kg} \text { of animal manure }+1 \mathrm{~L} \text { of activated } \mathrm{EM}+5 \mathrm{~kg} \text { of biochar } \\
(10 \%)+\text { Mixture of Rocks }\end{array}$ \\
\hline T7 & $50 \mathrm{~kg}$ of rice straw $+20 \mathrm{~kg}$ of cow manure $+10 \mathrm{~kg}$ of biochar $(20 \%)+$ Mixture of Rocks \\
\hline T8 & $\begin{array}{l}50 \mathrm{~kg} \text { of rice straw }+20 \mathrm{~kg} \text { of animal manure }+50 \mathrm{~g} \text { of Chinese starter }+10 \mathrm{~kg} \text { of biochar } \\
(20 \%)+\text { Mixture of Rocks }\end{array}$ \\
\hline T9 & $\begin{array}{l}50 \mathrm{~kg} \text { of rice straw }+20 \mathrm{~kg} \text { of animal manure }+1 \mathrm{~L} \text { of activated } \mathrm{EM}+10 \mathrm{~kg} \text { of biochar } \\
(20 \%)+\text { Mixture of Rocks }\end{array}$ \\
\hline
\end{tabular}

Table 3. Types of rocks used and their corresponding quantities.

\begin{tabular}{cccc}
\hline Type of rock & Percentage (\%) & Quantity $(\mathrm{Kg})$ & Value Added \\
\hline $\begin{array}{c}\text { Rock phosphate } \\
\text { Feldspar }\end{array}$ & $2.5 \%$ & 1.25 & Source of Phosphorous \\
Sulfur & $2.5 \%$ & 1.25 & $\begin{array}{c}\text { Source of Potassium } \\
\text { Dolomite }\end{array}$ \\
$\begin{array}{c}2.5 \% \\
\text { Bentonite }\end{array}$ & $10 \%$ & 1.25 & Natural Pesticide \\
& $5 \mathrm{~kg}$ & $\begin{array}{c}\text { Source of magnesium and calcium } \\
\text { potassium, and iron }\end{array}$ \\
\hline
\end{tabular}


collected after 60days to calculate the p-value and understand whether different treatments have a significant effect on the properties of the final product or not.

\section{Results and Discussion}

\subsection{Temperature Changes}

The temperature changes for the nine compost piles and corresponding ambient temperatures are measured three times a week at different location in the pile using a digital thermometer. The results are presented in Figure 1. This experiment is conducted during the summer season and the ambient temperature variations throughout the composting period were between $29^{\circ} \mathrm{C}$ and $40^{\circ} \mathrm{C}$.

An increase in piles temperatures was observed right after composting started. It is important to mention that this experiment was conducted in the summer season. Ambient temperature and treatments temperature were measured three times a week at different locations in the pile using a digital thermometer. The treatments are left three months for composting.

The temperatures increased rapidly to reach their maximum temperatures after 2 days in all treatments, which marks the end of the initial mesophilic phase and beginning of thermophilic phase. The increase in temperature during composting is due to the activity of microorganisms to degrade agricultural wastes [26] [27]. The highest temperature is observed in T3, T5 and T6 compared to other treatments, which indicates that these treatment has greater microbial activity.

After that, the temperatures started to decrease gradually, indicating a reduction in microbial activity. The observed fluctuations in temperature are due to the turning of pile. Then the temperature gradually decreased to reach mesophilic phase. After that, it stabilized near the ambient temperature after around 42 days.

\subsection{Organic Carbon (OC, \%) and Organic Matter (OM, \%)}

Three homogenized and randomized samples are taken manually after 10 days, 30 days and 60 days from top, middle and bottom of compost piles. The \%OM were measured for the nine piles, three measurements were taken for each pile, then the OM by weight is calculated from the total solid content (TS) and the results are presented in Table 4. It is also worth mentioning that the volume of the piles decreased by around $40 \%$ by the end of the composting process. One-way ANOVA was performed on the data after 60 days and results indicate that $\mathrm{p}$-value of 0.00 less than 0.05 confidence interval, which means that there is a significant difference between the means of different treatments.

Then $\% \mathrm{OC}$ were calculated from $\% \mathrm{OM}$ and average values are presented in Table 5.

The $\mathrm{OM}$ and $\mathrm{OC}$ decreases in all piles indicating that the organic substances are degraded and decomposed by micro-organisms [28]. The highest percentage losses are observed in T6 followed by $\mathrm{T} 5$. This reveals that these treatments have 

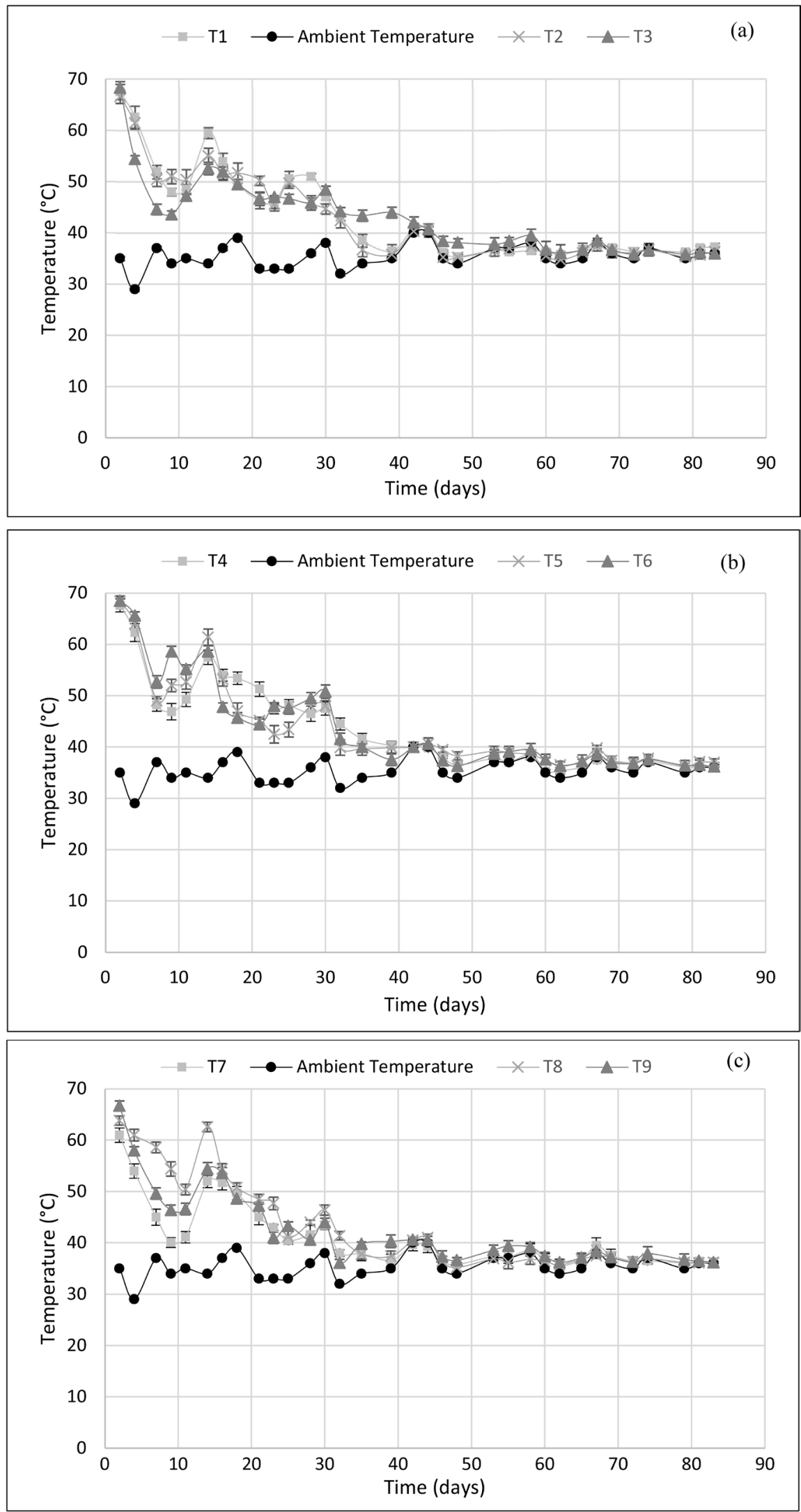

Figure 1. Changes in temperatures in compost piles with relation to ambient temperatures for (a) T1, T2 and T3, (b) T4, T5 and T6, (c) T7, T8 and T9. 
Table 4. Results of OM.

\begin{tabular}{|c|c|c|c|c|c|c|c|c|}
\hline & \multicolumn{3}{|c|}{ Average TS $(\mathrm{kg})^{\mathrm{a}}$} & \multicolumn{3}{|c|}{ Average OM $(\mathbf{k g})^{\mathrm{b}}$} & \multirow{2}{*}{$\begin{array}{c}\% \\
\text { losses } \\
\text { after } 30 \\
\text { days }^{c}\end{array}$} & \multirow{2}{*}{$\begin{array}{c}\% \\
\text { losses } \\
\text { after } 60 \\
\text { days }^{\mathrm{c}}\end{array}$} \\
\hline & Initial & $\begin{array}{c}\text { After } \\
30 \text { days }\end{array}$ & $\begin{array}{l}\text { After } \\
60 \text { days }\end{array}$ & Initial & $\begin{array}{c}\text { After } \\
30 \text { days }\end{array}$ & $\begin{array}{l}\text { After } \\
60 \text { days }\end{array}$ & & \\
\hline $\mathrm{T} 1$ & 17.5 & 14.8 & 13.6 & 10.7 & 8.2 & 5.1 & 23.6 & 52.4 \\
\hline $\mathrm{T} 2$ & 17.5 & 15.2 & 13.4 & 11.6 & 8.6 & 5.2 & 26.0 & 55.1 \\
\hline T3 & 17.5 & 16 & 13.6 & 10.9 & 8.7 & 4.8 & 20.3 & 55.9 \\
\hline $\mathrm{T} 4$ & 17.5 & 15.6 & 13 & 11.1 & 9.4 & 4.8 & 14.9 & 57.0 \\
\hline T5 & 18.5 & 13.6 & 13 & 12.6 & 7.9 & 5.0 & 37.1 & 60.6 \\
\hline T6 & 16.5 & 14.8 & 12.4 & 10.8 & 7.6 & 4.4 & 29.7 & 59.5 \\
\hline T7 & 20 & 13.2 & 13.4 & 12.6 & 6.9 & 5.9 & 45.2 & 53.1 \\
\hline $\mathrm{T} 8$ & 17.5 & 16 & 14 & 11.8 & 9.3 & 6.0 & 20.7 & 49.2 \\
\hline Т9 & 17 & 16.4 & 13.2 & 10.2 & 8.4 & 4.8 & 17.7 & 52.7 \\
\hline
\end{tabular}

${ }^{a}$ TS refers to total solid content; ${ }^{\mathrm{b}} \mathrm{OM}$ refers to Organic Matter; ${ }^{\mathrm{C}}$ The $\%$ losses are the difference in OM in all piles after 30 and 60 days.

Table 5. Results of OC.

\begin{tabular}{cccccc}
\hline & \multicolumn{3}{c}{ Average OC (kg) } & $\begin{array}{c}\% \\
\text { losses after 30 } \\
\text { days }\end{array}$ & $\begin{array}{c}\% \\
\text { losses after 60 } \\
\text { days }\end{array}$ \\
\cline { 2 - 5 } & Initial & After 30 days & After 60 days & 9.64 & 38.73 \\
T1 & 35.5 & 32.1 & 21.8 & 14.80 & 41.46 \\
T2 & 38.4 & 32.7 & 22.5 & 12.92 & 43.42 \\
T3 & 36 & 31.4 & 20.4 & 4.62 & 42.06 \\
T4 & 36.7 & 35 & 21.3 & 14.40 & 43.91 \\
T5 & 39.5 & 33.8 & 22.2 & 21.63 & 46.06 \\
T6 & 37.9 & 29.7 & 20.4 & 16.97 & 30.03 \\
T7 & 36.6 & 30.4 & 25.6 & 13.23 & 36.49 \\
T8 & 39 & 33.8 & 24.8 & 14.66 & 39.87 \\
T9 & 34.7 & 29.8 & 21.2 & & \\
\hline
\end{tabular}

high content of easily decomposable substances compared to other treatments. This results are in line with the results obtained from the temperature profile.

\subsection{Total Nitrogen, Ammonium and Nitrate Nitrogen}

The total nitrogen $(\mathrm{TN})$, ammonium nitrogen $\left(\mathrm{NH}_{4}^{+}\right)$and nitrate nitrogen $\left(\mathrm{NO}_{3}^{-}\right)$ were measured for all piles. Three measurements were taken for each pile. The average TN (\%) values are presented in Table 6.

One-way ANOVA was performed on the data of TN after 60 days and results indicate that $\mathrm{p}$-value of 0.00 less than 0.05 confidence interval, which means that there is a significant difference between the means of different treatments.

The results indicated that TN increased in some samples, while it decreased in others. In fact, TN slightly increased in treatments T1, T2 and T6 and decreased 
in all other treatments. Samples inoculated with biochar only (T5 and T7) showed relatively large TN loss, this could be attributed to relatively low $\mathrm{N}$ with high biodegradable material. These differences in TN could be due to difference in initial $\mathrm{C} / \mathrm{N}$ ratios coupled with differences in the initial amount of $\mathrm{TN}$ and $\mathrm{pH}$ values [29].

Ammonium and nitrate nitrogen are of greater interest, as they have been used as maturity index for composting [29] [30]. As shown in Figure 2 and Figure 3. The ammonia nitrogen decreased with time, while the nitrate nitrogen increases with time, which indicate that the nitrification process occurred [30].

From the above results the nitrification ratio is calculated and presented in Table 7. Some studies indicate that the ratio should not exceed 0.16 [31], while others reported ratios of 1 [29].

The results indicate that that nitrification ratios are high at the beginning of the treatments and decreased until maturity is reached. All treatments have a

Table 6. Results of total nitrogen.

\begin{tabular}{cccccccc}
\hline & \multicolumn{3}{c}{ Average TS (kg) } & \multicolumn{2}{c}{ Average OM (kg) } & $\begin{array}{c}\text { \%Gain (+) or } \\
\text { \%Loss (-) }\end{array}$ \\
\cline { 2 - 6 } & Initial & $\begin{array}{c}\text { After 30 } \\
\text { days }\end{array}$ & $\begin{array}{c}\text { After 60 } \\
\text { days }\end{array}$ & Initial & $\begin{array}{c}\text { After 30 } \\
\text { days }\end{array}$ & $\begin{array}{c}\text { After 60 } \\
\text { days }\end{array}$ & $\begin{array}{c}\text { after 60 days } \\
\text { aft }\end{array}$ \\
\hline T1 & 35.5 & 32.1 & 21.8 & 0.17 & 0.16 & 0.17 & -0.20 \\
T2 & 38.4 & 32.7 & 22.5 & 0.20 & 0.20 & 0.21 & +5.03 \\
T3 & 36 & 31.4 & 20.4 & 0.15 & 0.16 & 0.15 & -2.63 \\
T4 & 36.7 & 35 & 21.3 & 0.17 & 0.17 & 0.17 & -2.22 \\
T5 & 39.5 & 33.8 & 22.2 & 0.21 & 0.16 & 0.16 & -23.40 \\
T6 & 37.9 & 29.7 & 20.4 & 0.15 & 0.19 & 0.17 & +11.49 \\
T7 & 36.6 & 30.4 & 25.6 & 0.22 & 0.15 & 0.16 & -25.69 \\
T8 & 39 & 33.8 & 24.8 & 0.21 & 0.21 & 0.20 & -6.12 \\
T9 & 34.7 & 29.8 & 21.2 & 0.14 & 0.16 & 0.13 & -7.74 \\
\hline
\end{tabular}

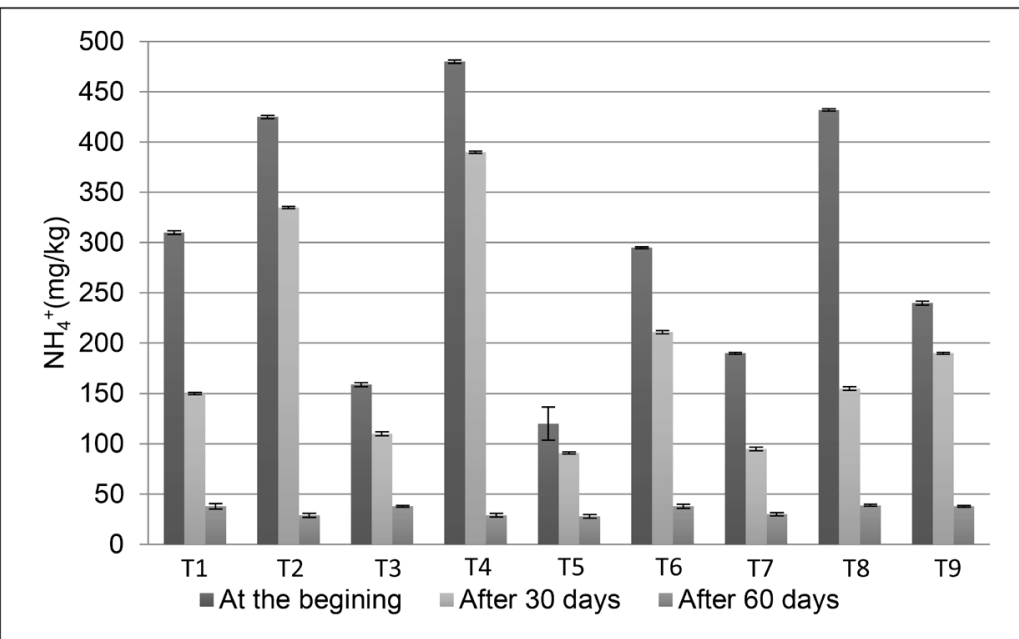

Figure 2. Ammonium nitrogen in different compost treatments. 


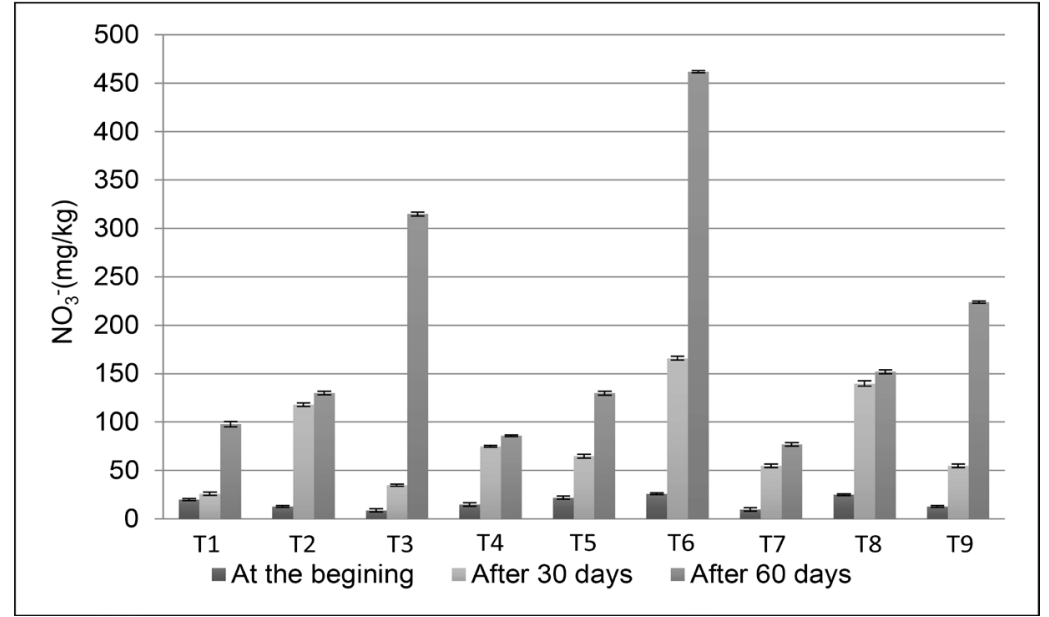

Figure 3. Nitrate nitrogen in different compost treatments.

Table 7. Types of rocks used and their corresponding quantities.

\begin{tabular}{cccc}
\hline Treatments & Initial & After $\mathbf{3 0}$ days & After 90 days \\
\hline T1 & 15.50 & 5.77 & 0.39 \\
T2 & 32.69 & 2.84 & 0.22 \\
T3 & 17.67 & 3.14 & 0.12 \\
T4 & 32.00 & 5.20 & 0.34 \\
T5 & 5.45 & 1.40 & 0.22 \\
T6 & 11.35 & 1.27 & 0.08 \\
T7 & 19.00 & 1.73 & 0.39 \\
T8 & 17.28 & 1.11 & 0.26 \\
T9 & 18.46 & 3.45 & 0.17 \\
\hline
\end{tabular}

nitrification ratio below 1 . Treatments inoculated with EM (T6, T3, T9) have a nitrification ratio below 0.16 . These results indicate that these treatments have highest maturity compared to other treatments.

\subsection{C/N Ratio}

The carbon to nitrogen ratio $(\mathrm{C} / \mathrm{N})$ is one of the most important factors that affect the composting process. In this experiment $\mathrm{C} / \mathrm{N}$ ratio is used to follow the degradation process of the compost piles as done in many other studies despite many pitfalls associated with this approach [32]. The $\mathrm{C} / \mathrm{N}$ ratio is calculated and presented in Figure 4. The results indicate that $\mathrm{C} / \mathrm{N}$ ratio of all piles are close or below 20 after 60 days of compositing, which is an indication of acceptable maturity [32] [33].

\subsection{Moisture Content and Bulk Density}

The moisture content and bulk density were measured for all piles as presented in Figure 5 and Figure 6 respectively.

The moisture content of all treatments initially ranged from $60 \%-67 \%$ and 


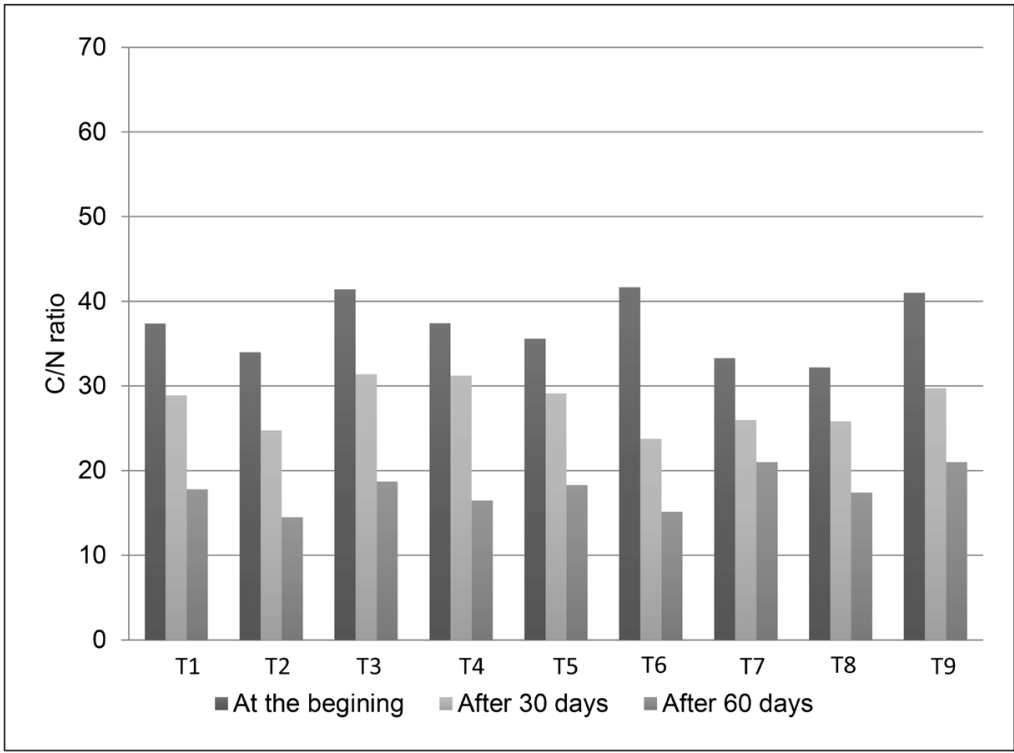

Figure 4. $\mathrm{C} / \mathrm{N}$ ratio of different compost treatments.

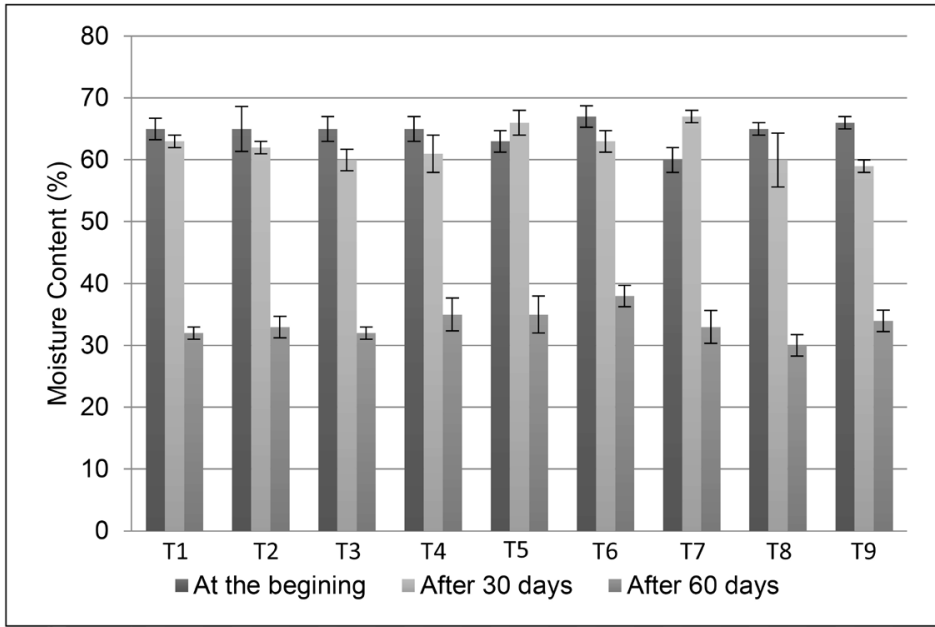

Figure 5. Moisture content in different compost treatments.

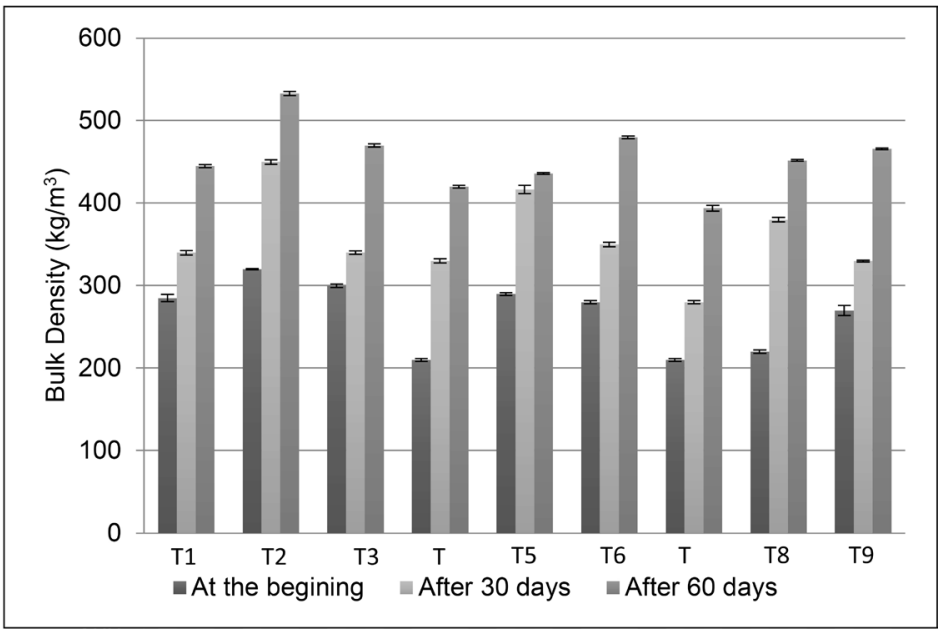

Figure 6. Bulk density of different compost treatments. 
decreased during the composting process to reach values in the range of $30 \%$ to $38 \%$. The bulk densities were initially $285 \mathrm{~kg} / \mathrm{m}^{3}, 320 \mathrm{~kg} / \mathrm{m}^{3}, 300 \mathrm{~kg} / \mathrm{m}^{3}, 210$ $\mathrm{kg} / \mathrm{m}^{3}$ and $290 \mathrm{~kg} / \mathrm{m}^{3} 280 \mathrm{~kg} / \mathrm{m}^{3}, 310 \mathrm{~kg} / \mathrm{m}^{3}, 320 \mathrm{~kg} / \mathrm{m}^{3}, 270 \mathrm{~kg} / \mathrm{m}^{3}$ respectively. These values increased to $445 \mathrm{~kg} / \mathrm{m}^{3}, 533 \mathrm{~kg} / \mathrm{m}^{3}, 470 \mathrm{~kg} / \mathrm{m}^{3}, 420 \mathrm{~kg} / \mathrm{m}^{3}, 536$ $\mathrm{kg} / \mathrm{m}^{3}, 480 \mathrm{~kg} / \mathrm{m}^{3}, 494 \mathrm{~kg} / \mathrm{m}^{3}, 552 \mathrm{~kg} / \mathrm{m}^{3}, 466 \mathrm{~kg} / \mathrm{m}^{3}$ respectively.

One-way ANOVA was performed on the data of bulk density after 60 days and results indicate that $\mathrm{p}$-value of 0.00 less than 0.05 confidence interval, which means that there is a significant difference between the means of different treatments.

The pile inoculated with EM and 10\% biochar (T6) showed highest bulk density. High bulk density values indicate higher level of activities in the decomposition of organic material to break down the loosely combined raw materials into smaller pieces [3]. This result indicates that $\mathrm{T} 6$ have the highest level of activities in the decomposition of organic material to break down the loosely combined raw materials into smaller pieces compared to all other treatments.

\section{6. $\mathrm{pH}$ and Electrical Conductivity (Ec)}

The electrical conductivity (EC) and $\mathrm{pH}$ of all piles were measured and presented in Figure 7 and Figure 8 respectively.

EC is a good indicator of the safety and suitability of compost. The EC of the finished compost of all treatments are ranging between 2.3 to $3.12 \mathrm{dS} \cdot \mathrm{m}^{-1}$. Some studies showed that values ranging between 2.0 to $6.0 \mathrm{dS} \cdot \mathrm{m}^{-1}$ are considered tolerable by plants [34] [35].

Also, the $\mathrm{pH}$ values of all piles after 90 days were ranging from 7.74 to 8.69 , which is in the recommended range from 7.5 to 8.5 [27].

\subsection{Germination Index (GI), Pathogenic Bacteria and Humification Index (HI)}

Germination index (GI) is a measure of phytotoxicity of compost; many studies

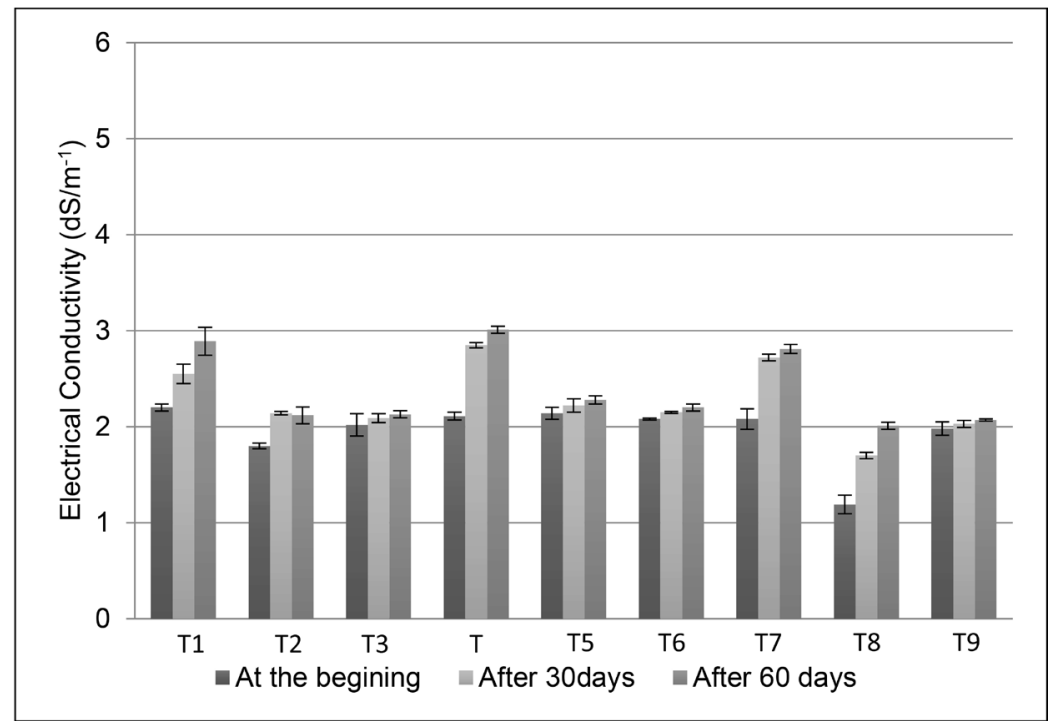

Figure 7. Electrical Conductivity of different compost treatments. 


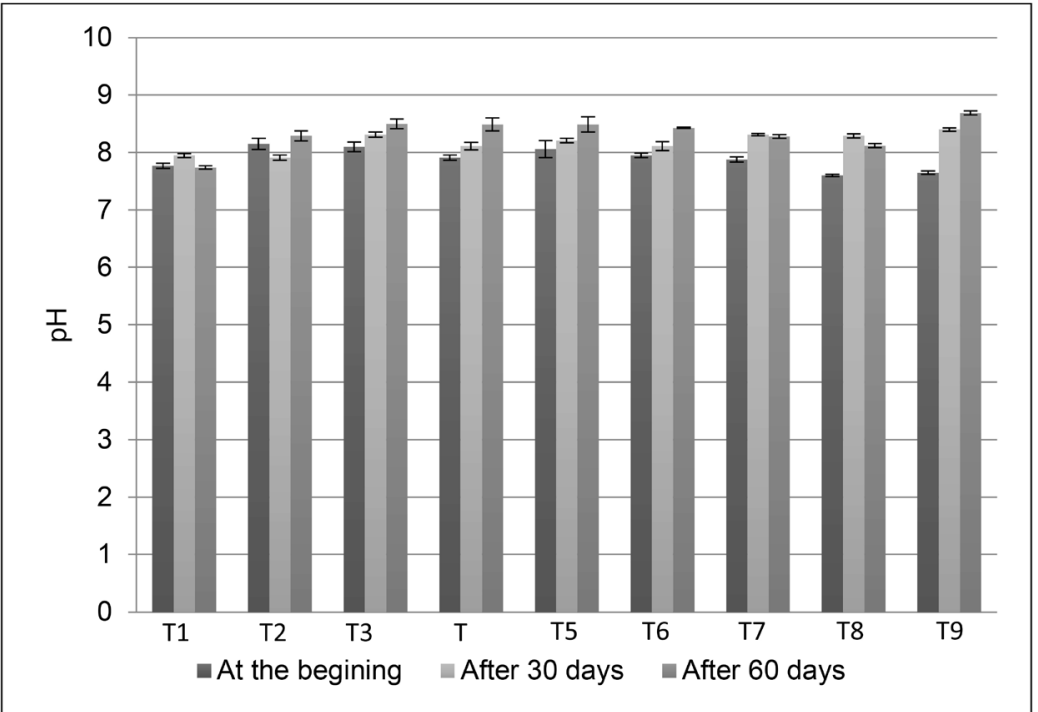

Figure 8. pH of different compost treatments.

Table 8. Germination Index and humification index for different treatments after 90 days of composting

\begin{tabular}{cccccccccc}
\hline Treatments & T1 & T2 & T3 & T4 & T5 & T6 & T7 & T8 & T9 \\
\hline Germination Index & 80 & 80 & 90 & 80 & 80 & 90 & 80 & 80 & 80 \\
Humification index & 1.4 & 1.7 & 1.9 & 1.5 & 1.8 & 1.9 & 1.6 & 1.6 & 1.7 \\
\hline
\end{tabular}

reported that a GI higher than $80 \%$ indicates the absence of phytotoxins in composts [3] [29]. According to Selim et al., GI ranging from 66 to 100 indicates absence of phytotoxicity [29]. The GI of all treatments is presented in Table 8. GI of all treatments are ranging from 80 to 90 , which indicates that all compost piles are free of phytotoxins.

The humification index (HI) is the ratio of the humic acid to the fulvic acid and is a measure of maturity of the compost. The recorded HI is greater than 1 for all treatments as presented in Table 8; therefore, all compost piles could be considered mature.

All final compost treatments were found free of pathogenic bacteria, as presented in Table 9, indicating their biosafety.

\subsection{Total Phosphorous (TP) and Total Potassium (TK)}

$\% \mathrm{TP}$ and \% $\mathrm{TK}$ were measured for all piles. Three measurements were taken for each pile. The average $\mathrm{TP}(\%)$ and $\mathrm{TK}(\%)$ values are presented in Table 10 respectively. According to El-Haddad et al. [36], the recommended range of TP (\%) is 0.4 to 1.1 and the recommended range of TK (\%) is 0.6 to 1.7 . The \%TP and $\% \mathrm{TK}$ of all treatments increased in the compost piles and were in final product in the recommended range (TP (\%) is 0.4 to 1.1 and TK (\%) is 0.6 to 1.7).

One-way ANOVA analysis of \%TP and \%TK after 60 days indicate that 
Table 9. Pathogenic bacteria for different treatments.

\begin{tabular}{|c|c|c|c|c|}
\hline & Treatments & Initial & After 30 days & After 60 days \\
\hline \multirow{8}{*}{$\begin{array}{l}\text { Total Coliform Count } \\
(\mathrm{cfu} / \mathrm{g})\end{array}$} & $\mathrm{T} 1$ & $9 \mathrm{E}+05$ & $3 \mathrm{E}+05$ & nd \\
\hline & $\mathrm{T} 2$ & $6 \mathrm{E}+05$ & $2 \mathrm{E}+05$ & nd \\
\hline & $\mathrm{T} 3$ & $5 \mathrm{E}+05$ & $2 \mathrm{E}+05$ & nd \\
\hline & $\mathrm{T} 4$ & $8 \mathrm{E}+05$ & $4 \mathrm{E}+05$ & nd \\
\hline & T5 & $7 \mathrm{E}+00$ & $3 \mathrm{E}+05$ & nd \\
\hline & T6 & $4 \mathrm{E}+05$ & $2 \mathrm{E}+05$ & nd \\
\hline & $\mathrm{T} 7$ & $6 \mathrm{E}+05$ & $3 \mathrm{E}+05$ & nd \\
\hline & $\mathrm{T} 8$ & $8 \mathrm{E}+05$ & $5 \mathrm{E}+05$ & nd \\
\hline \multirow{10}{*}{$\begin{array}{l}\text { Fecal Coliform Count } \\
(\mathrm{cfu} / \mathrm{g})\end{array}$} & T9 & $6 \mathrm{E}+05$ & $3 \mathrm{E}+05$ & nd \\
\hline & $\mathrm{T} 1$ & $5 \mathrm{E}+05$ & $2 \mathrm{E}+05$ & nd \\
\hline & $\mathrm{T} 2$ & $4 \mathrm{E}+05$ & $2 \mathrm{E}+05$ & nd \\
\hline & $\mathrm{T} 3$ & $3 \mathrm{E}+05$ & $1 \mathrm{E}+05$ & nd \\
\hline & $\mathrm{T} 4$ & $4 \mathrm{E}+05$ & $2 \mathrm{E}+05$ & nd \\
\hline & T5 & $5 \mathrm{E}+05$ & $2 \mathrm{E}+05$ & nd \\
\hline & T6 & $3 \mathrm{E}+05$ & $1 \mathrm{E}+05$ & nd \\
\hline & T7 & $2 \mathrm{E}+05$ & $1 \mathrm{E}+05$ & nd \\
\hline & $\mathrm{T} 8$ & $4 \mathrm{E}+05$ & $2 \mathrm{E}+05$ & nd \\
\hline & T9 & $3 \mathrm{E}+05$ & $1 \mathrm{E}+05$ & nd \\
\hline \multirow{9}{*}{$\begin{array}{c}\text { Salmonella and } \\
\text { Shigella count }(\mathrm{cfu} / \mathrm{g})\end{array}$} & $\mathrm{T} 1$ & $2.00 \mathrm{E}+05$ & $1 \mathrm{E}+05$ & nd \\
\hline & $\mathrm{T} 2$ & $4.00 \mathrm{E}+05$ & $2 \mathrm{E}+05$ & nd \\
\hline & $\mathrm{T} 3$ & $1.00 \mathrm{E}+05$ & nd & nd \\
\hline & $\mathrm{T} 4$ & $3.00 \mathrm{E}+05$ & $2 \mathrm{E}+05$ & nd \\
\hline & T5 & $3.00 \mathrm{E}+05$ & $1 \mathrm{E}+05$ & nd \\
\hline & T6 & $2.00 \mathrm{E}+05$ & $1 \mathrm{E}+05$ & nd \\
\hline & $\mathrm{T} 7$ & $2.00 \mathrm{E}+05$ & $1 \mathrm{E}+05$ & nd \\
\hline & T8 & $4.00 \mathrm{E}+05$ & $2 \mathrm{E}+05$ & nd \\
\hline & T9 & $3.00 \mathrm{E}+05$ & $2 \mathrm{E}+05$ & nd \\
\hline
\end{tabular}

nd refers to not detected.

p-value of 0.00 less than 0.05 confidence interval, which means that there is a significant difference between the means of different treatments, which means that each additive has a different effect on the final \%TP and \%TK of compost pile.

Table 10 compares the values of TP and TK by weight (in $\mathrm{kg}$ ). The results are in line with results obtained from the \%TP and \%TK. There is an increase in total phosphorous and total potassium values during composting.

The highest values were obtained in T6 containing EM and 10\% biochar. It is also important to notice that increasing the percentage of biochar to $10 \%$ has 
Table 10. Results of total phosphorous.

\begin{tabular}{ccccccccc}
\hline & \multicolumn{3}{c}{ Average TP (kg) } & \multicolumn{5}{c}{ Average TK (kg) } \\
\cline { 2 - 9 } & Initial & $\begin{array}{c}\text { After 30 } \\
\text { days }\end{array}$ & $\begin{array}{c}\text { After 60 } \\
\text { days }\end{array}$ & \% gain & Initial & $\begin{array}{c}\text { After 30 } \\
\text { days }\end{array}$ & $\begin{array}{c}\text { After 60 } \\
\text { days }\end{array}$ & \% gain \\
\hline T1 & 0.0013 & 0.0014 & 0.0015 & 12.4 & 0.0012 & 0.0013 & 0.0016 & 37.8 \\
T2 & 0.0016 & 0.0016 & 0.0018 & 12.7 & 0.0014 & 0.0017 & 0.0019 & 30.9 \\
T3 & 0.0012 & 0.0015 & 0.0016 & 36.1 & 0.0016 & 0.0019 & 0.0019 & 18.3 \\
T4 & 0.0013 & 0.0016 & 0.0016 & 31.3 & 0.0013 & 0.0011 & 0.0019 & 52.7 \\
T5 & 0.0018 & 0.0018 & 0.0018 & 1.3 & 0.0013 & 0.0014 & 0.0018 & 37.4 \\
T6 & 0.0012 & 0.0017 & 0.0019 & 52.3 & 0.0017 & 0.0023 & 0.0027 & 59.3 \\
T7 & 0.0013 & 0.0012 & 0.0013 & 3.8 & 0.0012 & 0.0011 & 0.0013 & 8.8 \\
T8 & 0.0018 & 0.0019 & 0.0018 & 1.6 & 0.0015 & 0.0015 & 0.0016 & 7.5 \\
T9 & 0.0011 & 0.0014 & 0.0011 & 3.0 & 0.0011 & 0.0013 & 0.0011 & 7.2 \\
\hline
\end{tabular}

increased the quality of the compost. However, further increase of biochar to $20 \%$ decreased the quality of the compost.

\section{Conclusion}

The results revealed that the application of different additives in composting of rice straw exhibits an improvement in maturation time and final product quality. In fact, all piles reached maturation after around 42 days. All analysis of the properties of the final products indicated that it was in the range of the matured level and can be used without any limitation as an organic fertilizer. The highest decomposition rate and highest organic fertilizer quality were obtained in pile containing rice straw and $40 \%$ of animal manure mixed with natural rocks $(2.5 \%$ of rock phosphate, $2.5 \%$ feldspar, $2.5 \%$ sulfur, $2.5 \%$ dolomite and $10 \%$ bentonite) and inoculated with $2 \%$ of EM and $10 \%$ biochar compared to other treatments. Also, the results showed that adding $20 \%$ biochar decreased the quality of the final compost compared to adding $10 \%$.

\section{Conflicts of Interest}

The authors declare no conflicts of interest regarding the publication of this paper.

\section{References}

[1] Kamel, S., El-Sattar, H.A., Vera, D. and Jurado, F. (2018) Bioenergy Potential from Agriculture Residues for Energy Generation in Egypt. Renewable and Sustainable Energy Reviews, 94, 28-37. https://doi.org/10.1016/j.rser.2018.05.070

[2] Nakhla, D.A., Hassan, M.G. and El-Haggar, S. (2013) Impact of Biomass in Egypt on Climate Change. Natural Science, 5, 678-684. https://doi.org/10.4236/ns.2013.56083

[3] Abdel-Rahman, A.M., El-Din, M.N., Refaat, B.M., Abdel-Shakour, E.H., El-Din 
Ewais, E. and Alrefaey, H.M.A. (2016) Biotechnological Application of Thermotolerant Cellulose-Decomposing Bacteria in Composting of Rice Straw. Annals of Agricultural Science, 61, 135-143. https://doi.org/10.1016/j.aoas.2015.11.006

[4] Abdelhady, S. and Rispoli, F. (2014) Viability Study of Biomass Power Plant Fired with Rice Straw in Egypt. Energy Procedia, 61, 211-215.

https://doi.org/10.1016/j.egypro.2014.11.1072

[5] Abdel-Rahman, M.A., Tashiro, Y. and Sonomoto, K. (2011) Lactic Acid Production from Lignocellulose-Derived Sugars Using Lactic Acid Bacteria: Overview and Limits. Journal of biotechnology, 156, 286-301.

https://doi.org/10.1016/j.jbiotec.2011.06.017

[6] Sakdaronnarong, C. and Jonglertjunya, W. (2012) Rice Straw and Sugarcane Bagasse Degradation Mimicking Lignocellulose Decay in Nature: An Alternative Approach to Biorefinery. Science Asia, 38, 364-372.

https://doi.org/10.2306/scienceasia1513-1874.2012.38.364

[7] El Haggar, S. (2007) Sustainable Industrial Design and Waste Management: Cradle-to-Cradle for Sustainable Development. Elsevier Science, Amsterdam. https://doi.org/10.1016/B978-012373623-9/50012-5

[8] Omar, H. and El Haggar, S. (2017) Zero Waste Rural Community Complex (ZWRC2). Environmental Management and Sustainable Development, 6, 105-118. https://doi.org/10.5296/emsd.v6i1.10601

[9] Qian, X.Y., et al. (2014) Co-Composting of Livestock Manure with Rice Straw: Characterization and Establishment of Maturity Evaluation System. Waste Management, 34, 530-535. https://doi.org/10.1016/j.wasman.2013.10.007

[10] Bernal, M.P., Alburquerque, J.A. and Moral, R. (2009) Composting of Animal Manures and Chemical Criteria for Compost Maturity Assessment. A Review. Bioresource Technology, 100, 5444-5453. https://doi.org/10.1016/j.biortech.2008.11.027

[11] He, M.M., Li, W.H., Liang, X.Q., Wu, D.L. and Tian, G.M. (2009) Effect of Composting Process on Phytotoxicity and Speciation of Copper, Zinc and Lead in Sewage Sludge and Swine Manure. Waste Management, 29, 590-597. https://doi.org/10.1016/j.wasman.2008.07.005

[12] De Guardia, A., et al. (2010) Comparison of Five Organic Wastes Regarding Their Behaviour during Composting: Part 1, Biodegradability, Stabilization Kinetics and Temperature Rise. Waste Management, 30, 402-414. https://doi.org/10.1016/j.wasman.2009.10.019

[13] Liu, D.Y., et al. (2011) Changes in Biochemical and Microbiological Parameters during the Period of Rapid Composting of Dairy Manure with Rice Chaff. Bioresource Technology, 102, 9040-9049. https://doi.org/10.1016/j.biortech.2011.07.052

[14] Sánchez-García, M., Alburquerque, J.A., Sánchez-Monedero, M.A., Roig, A. and Cayuela, M.L. (2015) Biochar Accelerates Organic Matter Degradation and Enhances N Mineralisation during Composting of Poultry Manure without a Relevant Impact on Gas Emissions. Bioresource Technology, 192, 272-279. https://doi.org/10.1016/j.biortech.2015.05.003

[15] Barthod, J., Rumpel, C. and Dignac, M.-F. (2018) Composting with Additives to Improve Organic Amendments. A Review. Agronomy for Sustainable Development, 38, 17. https://doi.org/10.1007/s13593-018-0491-9

[16] Anwar, Z., Irshad, M., Fareed, I. and Saleem, A. (2015) Characterization and Recycling of Organic Waste after Co-Composting-A Review. Journal of Agricultural Science, 7, 68-79. https://doi.org/10.5539/jas.v7n4p68

[17] Jusoh, M.L.C., Abd Manaf, L. and Abdul Latiff, P. (2013) Composting of Rice Straw 
with Effective Microorganisms (EM) and Its Influence on Compost Quality. Iranian Journal of Environmental Health Science \& Engineering, 10, 17. https://doi.org/10.1186/1735-2746-10-17

[18] Sánchez-Monedero, M.A., Cayuela, M.L., Roig, A., Jindo, K., Mondini, C. and Bolan, N. (2018) Role of Biochar as an Additive in Organic Waste Composting. Bioresource Technology, 247, 1155-1164. https://doi.org/10.1016/j.biortech.2017.09.193

[19] Liu, N., Zhou, J.L., Han, L.J., Ma, S.S., Sun, X.X. and Huang, G.Q. (2017) Role and Multi-Scale Characterization of Bamboo Biochar during Poultry Manure Aerobic Composting. Bioresource Technology, 241, 190-199. https://doi.org/10.1016/j.biortech.2017.03.144

[20] Tiquia, S.M. and Tam, N.F.Y. (1998) Composting of Spent Pig Litter in Turned and Forced-Aerated Piles. Environmental Pollution, 99, 329-337. https://doi.org/10.1016/S0269-7491(98)00024-4

[21] Chapman, H.D. and Pratt, P.F. (1962) Methods of Analysis for Soils, Plants and Waters. Soil Science, 93, 68. https://doi.org/10.1097/00010694-196201000-00015

[22] Lu, K. (2000) Agricultural Chemical Analysis Methods. China Agricultural Science and Technology Press, Beijing.

[23] Zucconi, F. (1981) Evaluating Toxicity of Immature Compost. Biocycle, 22, 54-57.

[24] Ciavatta, C., Govi, M., Vittori Antisari, L. and Sequi, P. (1990) Characterization of Humified Compounds by Extraction and Fractionation on Solid Polyvynilpyrrolidone. Journal of Chromatography, 509, 141-146. https://doi.org/10.1016/S0021-9673(01)93248-0

[25] Snell, F.D. and Snell, C.T. (1954) Colorimetric Methods of Analysis. D. Van Nostrand Company, Inc., New York.

[26] Hassen, A., Belguith, K., Jedidi, N., Cherif, A., Cherif, M. and Boudabous, A. (2001) Microbial Characterization during Composting of Municipal Solid Waste. Bioresource Technology, 80, 217-225. https://doi.org/10.1016/S0960-8524(01)00065-7

[27] Makan, A., Assobhei, O. and Mountadar, M. (2012) Effect of Initial Moisture Content on the In-Vessel Composting under Air Pressure of Organic Fraction of $\mathrm{Mu}$ nicipal Solid Waste in Morocco. Iranian Journal of Environmental Health Science \& Engineering, 10, 3. https://doi.org/10.1186/1735-2746-10-3

[28] Barrington, S., Choinière, D., Trigui, M. and Knight, W. (2002) Effect of Carbon Source on Compost Nitrogen and Carbon Losses. Bioresource Technology, 83, 189-194. https://doi.org/10.1016/S0960-8524(01)00229-2

[29] Sánchez-Monedero, M.A., Roig, A., Paredes, C. and Bernal, M.P. (2001) Nitrogen Transformation during Organic Waste Composting by the Rutgers System and Its Effects on $\mathrm{pH}, \mathrm{EC}$ and Maturity of the Composting Mixtures. Bioresource Technlology, 78, 301-308. https://doi.org/10.1016/S0960-8524(01)00031-1

[30] Selim, S.M., Zayed, M.S. and Atta, H.M. (2012) Evaluation of Phytotoxicity of Compost during Composting Process. Nature and Science, 10, 69-77.

[31] Bernal, M.P., Paredes, M.A., Sanchez-Monedero, M.A. and Cegarra, J. (1998) Maturity and Stability Parameters of Composts Prepared with a Wide Range of Organic Wastes. Bioresources Technology, 63, 91-99. https://doi.org/10.1016/S0960-8524(97)00084-9

[32] Khalil, A., Beheary, M. and Salem, E. (2001) Monitoring of Microbial Populations and Their Cellulolytic Activities during the Composting of Municipal Solid Wastes. World Journal of Microbiology \& Biotechnology, 17, 155-161. https://doi.org/10.1023/A:1016682329925 
[33] Al-Barakah, F., Samir, R. and Abdel-Aziz, R. (2013) Using Biotechnology in Recycling Agricultural Waste for Sustainable Agriculture and Environmental Protection. International Journal of Current Microbiology and Applied Sciences, 2, 446-459.

[34] Brinton, W.F. (2000) Compost Quality Standards and Guidelines: An International View. ME, Woods End Research Laboratory Inc.

[35] Lasaridi, K., Protopapa, I., Kotsou, M., Pilidis, G., Manios, T. and Kyriacou, A. (2006) Quality Assessment of Composts in the Greek Market: The Need for Standards and Quality Assurance. Journal of Environmental Management, 80, 58-65. https://doi.org/10.1016/j.jenvman.2005.08.011

[36] El-Haddad, M.E., Zayed, M.S., El-Sayed, G.A.M., Hassanein, M.K. and Abd El-Satar, A.M. (2014) Evaluation of Compost, Vermicompost and Their Teas Produced from Rice Straw as Affected by Addition of Different Supplements. Annals of Agricultural Science, 59, 243-251. https://doi.org/10.1016/j.aoas.2014.11.013 